\title{
Integration or disintegration? Human resource implications of a common corporate language decision in a crossborder merger
}

\section{Rebecca Piekkari, Eero Vaara, Janne Tienari and Risto Sdntti}

\begin{abstract}
The primary purpose of introducing a common corporate language in crossborder mergers is to integrate two previously separate organizations and facilitate communication. However, the present case study of a cross-border merger between two Nordic banks shows that the common corporate language decision may have disintegrating effects, particularly at organizational levels below top management. We identify such effects on performance appraisal, language training and management development, career paths, promotion and key personnel. Our findings show that top management needs to work through the consequences of the language decision upon those who are expected to make such a decision work.
\end{abstract}

Keywords Mergers and acquisitions; post-merger integration; language.

The number of mergers and acquisitions (M\&As) has been increasing over the past years, although study after study of past mergers has shown that two out of every three deals have not worked and fewer than half of all mergers add value in medium term \{The Economist, 1999a), One of the factors to blame for the failure of these deals is the sociocultural, human side of mergers (Buono and Bowditch, 1989), the so-called 'soft trap' (The Economist, 1999b). Executives who have been through the merger process are now starting to recognize that the management of the human side is the real key to maximizing the value of mergers (Buono and Bowditch, 1989; Gertsen et al., 1998; Lohrum, 1996; Olie, 1994), During periods of massive recruitment and simultaneous layoffs coupled with uncertainty recognizing, retaining and motivating talented personnel is a critical ingredient of successful post-merger integration (Kay and Shelton, 2000),

Interestingly, however, there is little mention of human resource issues in analysing motives or planning for mergers (Cartwright and Cooper, 1990, 1993; Napier et aL, 1989; Morosini and Sing, 1994), Once the merger has been negotiated and it is time to implement it or assess its outcomes, however, human resource issues come to the fore (Buono and Bowditch, 1989), It is argued that the impact of a merger may be manifested in high turnover 
among key managers, power struggles among those managers who stay, lowered commitment and productivity, and increased dissatisfaction and disloyalty at all organizational levels. In order to reduce these negative effects and the personal uncertainty perceived among employees, communication is likely to play a central role (Bastien, 1987; Napier era/., 1989; Schweigeref a/., 1994; Schweiger and Denisi, 1991). Prior research on communication in mergers suggests that management should communicate with employees as soon as possible about all the anticipated effects of the merger (Risberg, 1999; Schweiger and Denisi, 1991). In merger situations employees have a tendency to use both formal and informal information sources to reduce feelings of uncertainty. Yet they often experience that they are not fully informed and that they do not get the 'full story' of the merger (Napier et al., 1989). As Schweiger and Denisi suggest, 'any failure to communicate leaves employees uncertain about their futures, and it is often that uncertainty, rather than the changes themselves, that is so stressful to employees' (1991: 110).

While much of the literature on M\&As emphasizes the importance of communication in reducing employee resistance and achieving effective integration (e.g. Bastien, 1987; Napier et al., 1989; Schweiger and Denisi, 1991), the context of these studies tends to be domestic. It is obvious that communication challenges encountered in cross-border M\&As are more severe than in domestic combinations (Larsson and Risberg, 1998). Greater workforce diversity in terms of linguistic and cultural differences is likely to complicate communication, as a common basis of shared assumptions and experiences becomes harder to establish.

Despite this, language issues and communication competence are often neglected in cross-border M\&As (see for exceptions, e.g., Gertsen and S0derberg, 1998; LouhialaSalminen, 2002). In their study of seven Danish electronics companies acquired by foreign companies during 1990-4 Gertsen and S0derberg (1998) observe that Danish employees were at a disadvantage when foreign management fixed the agenda in their own native language. Their findings show that active participation and exchange of views concerning the future strategy of the firm required such a high standard of English that Danish engineers and shop stewards could not contribute. Despite the fact that Danes are generally good at foreign languages, only very few Danes mastered English well enough to participate in integration discussions. Gertsen and SOderberg's study shows that language skills tend to vary considerably between groups of employees. Louhiala- Salminen (2002) investigated 
communication and language use in two Einnish-Swedish mergers. She found that the most significant change was the increased use of non-native languages such as English.

Thus, the purpose of this article is to examine the human resource management implications of introducing a common corporate language in a cross-border merger. When much of the employee communication is in a foreign language, additional personal uncertainty and suspicion are brought to the merger situation. In the early stage of the merger, the chosen corporate language is likely to send an implicit symbolic message regarding the division of power between the merging parties. In the implementation stage, language problems may render the work of transition teams more difficult and delay integration efforts. Whatever language is chosen, it may not necessarily remove integration problems but could instead escalate them and introduce a number of human resource management issues to be dealt with. In this article, we especially discuss human resource management activities related to performance appraisal, career paths and promotion, language training and management development, and key personnel.

The article is organized as follows. We first define the integration challenge in crossborder mergers and discuss the choice of the common corporate language. Thereafter, we describe the methodology, an in-depth case study drawing on rich ethnographic material on the merger between the Finnish Merita Bank and the Swedish Nordbanken. Our analysis concentrates on the Finnish viewpoint conceming the choice of Swedish as the common corporate language. The period of analysis extends itself from the announcement of the MeritaNordbanken (MNB) merger in October 1997 to the announcement of a subsequent merger between MNB and the Danish financial services group Unidanmark in March 2000. Third, we discuss the effect of the common corporate language decision on human resource management activities in the merged organization. The concluding section summarizes the findings and proposes some directions of future research.

\section{Cross-border mergers: an integration challenge}

A cross-border merger can be defined as a transaction in which 'the assets and operations of two firms belonging to two different countries are combined to establish a new legal entity' (UNCTAD, 2000: 99), Furthermore, cross-border mergers can be classified as horizontal, vertical and conglomerate (ibid,, 2000), In this article, we focus our discussion on horizontal mergers that take place between competing firms in the same industry. These mergers are 
primarily undertaken to achieve synergies and greater market power. For example, in 1998 the manufacturer of workaday transportation Chrysler merged with the luxury car manufacturer Daimler-Benz because, even as number three in the world's car market, Chrysler was regarded as too small to prosper alone (The Economist, 2000a),

In everyday speak, the terms 'merger' and 'acquisition' are often used interchangeably. However, a true merger in a sense of 'a marriage between equals' is very rare (Hogan and Overmyer-Day, 1994). Mergers introduce complex leadership challenges such as cochairman, co-chief executive, new name of the merged organization and location of its corporate headquarters. Many deals, which are in fact acquisitions, are described as mergers for political reasons to avoid the seeming dominance by one firm. For example, the merger between Daimler-Benz and Chrysler was announced as 'a marriage of equals', A few years later, however, Mr Schrempp, CEO of DaimlerChrysler, is reported to have admitted that the comment regarding the 'marriage of equals' was, from the start, a mere trick to sell the deal to Chrysler top management and boost the ego of Chrysler's CEO (The Economist, 2000c), Indeed, the Americans had a justifiable feeling that Daimler was the dominant party in this merger \{The Economist, 2000b),

Compared to domestic mergers, cross-border deals introduce extra layers of difficulty. Language and communication challenges are intertwined with cultural differences. The socalled 'cultural clash' may be caused by corporate as well as national differences. This concept describes a phenomenon experienced by members of one culture who feel disruptive tension when required to interact with a second culture and adopt its ways (Berry, 1983; Nahavandi and Malekzadeh, 1988). Researchers have thereby increasingly studied M\&As from a cultural perspective (Calori et al., 1994; Gertsen et al., 1998; Morosini and Sing, 1994; Olie, 1994; Sales and Mirvis, 1984; Vaara, 2000; Weber et al., 1996). These researchers argue that, since representatives of different nationalities are socialized into different skills, rules and habits, interaction between merging parties is likely to cause misunderstandings. The merging parties are seen to be in two opposing camps (e.g, Nahavandi and Malekzadeh, 1988; Olie, 1994). Such cultural juxtaposition, where actors strongly identify themselves with a particular national company, hampers post-merger integration processes. Indeed, many case studies provide supporting evidence of enduring cultural confrontation (see, e.g., Olie, 1994). 


\section{The common corporate language}

In much of the organizational research, language has always been on the agenda but typically it has been presented as a pragmatic problem related to top management's concerns for organizational effectiveness. It has merely been viewed as a medium of communication and not subjected to theoretical problematization and investigation. As a field of study, the relationship between language and organization is still in its infancy (for critical reflections, see Westwood and Linstead, 2001).

Recently, however, the choice and use of languages in multinational corporations have attracted interest among international management scholars (Barner-Rasmussen, 2003; Feely and Harzing, 2003; Holden, 2002; Marschan-Piekkari et ai, 1999a, 1999b; Yoshihara, 2001) as well as business communication researchers (Nickerson, 2000). Much of this work has focused on internal communication in multinationals and on the role of language in headquarter-subsidiary and inter-subsidiary relationships. The findings suggest that multinational corporations can be conceptualized as multilingual organizations (BarnerRasmussen and Bjorkman, 2003) in which language may operate as a barrier (Feely and Harzing, 2003), a resource (Holden, 2002; Barner-Rasmussen, 2003; Marschan-Piekkari et al., 1999b) or a source of power (Marschan-Piekkari et al., 1999b), with wide-ranging implications for control, communication and coordination in the multinational corporation.

The context of the present article - a cross-border merger - introduces language issues into an inter-organizational sphere in which two previously separate organizations are united (see also Louhiala-Salminen, 2002; Santti, 2001). Since Europe is culturally and linguistically extremely diverse, the issue of a common corporate language in postmerger integration becomes particularly pertinent. While top management's language competences are likely to be sufficient, employees lower down in the organizational hierarchy may lack the necessary skills to interact effectively with representatives of the other party and be unprepared to meet the new communication requirements of the merged company. Because of language-related problems, efforts to implement a' common vision for the new merged organization may be undermined and various integration projects may be delayed (Gertsen and SOderberg, 1998).

To overcome some of these problems, top management may decide to choose a common corporate language. The purpose of introducing such a language is to integrate the merging companies with each other and minimize the negative effects of language diversity. 
More specifically, as argued by Marschan-Piekkari et al. (1999a: 379), a corporate language aims at facilitating formal reporting within the company, thus minimizing the potential for miscommunication and providing easy access to company documents, such as technical, product manuals and financial reports; at enhancing informal communication and information exchanges between units; and at fostering a sense of belonging to one corporate 'family', which plays an important role in strengthening the corporate culture. These issues represent internal reasons for introducing a common corporate language. Another source of drivers for choosing a common corporate language can be found in the external business environment of the company. Firms need to take into account the language preferences of their key customers, suppliers and collaborative partners overseas (Feely, 2003).

In cross-border mergers, the choice of the common corporate language is a central element in reconstructing a new corporate culture and balancing power between merging parties. It can be assumed that the more infiuential party of the merger will nominate its preferred idiom as the common corporate language. However, in DaimlerChrysler's case, English - instead of German - was chosen although the German party was commonly considered the more dominant and powerful in this merger (The Economist, 2000b), This can be explained by the need to signal the international character of DaimlerChrysler \{Financial Times, 2001) and the importance of the US market dictating the increased use of English as the working language in the merged organization. Overall, due to the role of English as the lingua franca and its dominance as the world language in conducting intemational business, it tends to become the common corporate language by default.

English may also be chosen as a neutral language to emphasize equality between merging parties of non-English origin, and in this way balance the relationships within the merged organization. For example, in January 2000, the German Hoechst and the French Rhone-Poulenc merged creating the fifth largest pharmaceutical company in the world. The new organization, called Aventis, adopted English for internal communication to avoid favouring either the German- or the French-speaking group within the corporation \{Kauppalehti, 2000).

The implementation of the common corporate language is a multifaceted process. As it may take a long time before the necessary language competence is achieved throughout the merged organization, communication flows may be halting. In the meantime, only a small 
group of top managers may actually operate in the corporate language and most staff will continue using their national idioms. More importantly, language may carry social implications of belonging to a group (Victor, 1992), The inability to operate in the corporate language may result in various pattems of social inclusion and exclusion: on the one hand, some individuals may be marginalized due to their limited language competence; on the other hand, language skills may function as a source of informal, expert power. For example, as Pettigrew argues, 'gatekeepers, those who sit at the junction of a number of communication channels, are in a position to regulate' (1972: 190) the information flows and potentially control decisions. Managers and staff with the right language skills may easily occupy such gatekeeping positions and channel information between merging organizations. They may form language-based networks for accessing information and knowledge faster than through alternative communication channels (Marschan-Piekkari et al., 1999b). In this way, the status of languagecompetent staff may increase far beyond their formal, hierarchical position. Consequently, the corporate language may cause distance and isolation within the merged firm.

From a human resource management perspective, the choice of the corporate language may send an implicit message regarding career progression; in order to reach the top echelons of the organization, fluency in the common company language becomes a prerequisite (Marschan-Piekkari et al., 1999a), The intended effect of introducing a corporate language is to put pressure on individual employees to become competent in this language. This is important since the corporate language is used for all internal communication, in training and development programmes, as well as in international meetings. However, in the turmoil of corporate reorganization and uncertainty associated with most mergers, key persons may actually leave the organization (Hambrick and Cannella, 1993; Kay and Shelton, 2000), In some cases, the chosen corporate language may contribute to the departure of these individuals, particularly if the selected language requires considerable investments in terms of learning and time.

\section{An ethnographic case study}

The case of the Nordic merger between the Finnish Merita Bank and the Swedish Nordbanken (MeritaNordbanken, from here onwards referred to as MNB)' was chosen because of the apparent impact that the choice of Swedish as the common corporate language 
had on the merger implementation and outcome, particularly on human resource management. We investigated MNB over the period 1997-2000. The case provides us with an interplay between three languages: Finnish, Swedish and English as the lingua franca of the banking industry. Our analysis focuses on the Finnish side of the merged organization, where 94 per cent of the staff had Finnish as their mother tongue and only 6 per cent had Swedish.

The present investigation is an ethnographic case study in which observation and participation are interwoven with other data collection methods such as interviews (Flick, 2002: 146). In their review of twenty years of research on IHRM, Clark et al. (1999: 535) identify 'a lack of studies with either a broad historical or detailed ethnographic orientation'. We chose an ethnographic approach for two main reasons: first, the existing literature on human resource management implications of the common corporate language was too scant to form a basis for formulating and testing hypotheses; and, second, the emotional quality of individual reactions to the common corporate language was best captured by this approach. It provided us with intimate knowledge of the issue under investigation, allowing us to create close relationships with the case company and its members and place the research phenomenon in a broader societal context.

\section{Data}

Data for this case study were collected primarily through participant observation, providing rich ethnographic material supplemented with thematic interviews with current and former employees of MNB.

First, one of the authors of this article had been employed by MNB and its preceding organizations since 1989. As a manager in the personnel human resource development unit in Finland, he had a unique opportunity to observe how Finnish and Swedish managers and staff reacted to the merger. More specifically, he was intimately involved in developing a language training policy for the Finnish organization within MNB. This work generated material concerning a wide range of language challenges. He was also the leader and facilitator of cultural seminars for some 350 middle managers and experts involved in cross-national collaboration. In these seminars, taking place from October 1998 to January 2000, the choice and use of Swedish as the common corporate language were thoroughly debated. Since these seminars were held in Swedish, they clearly revealed problems among the Finnish participants such as inability to express oneself fluently on complicated matters and fatigue 
caused by efforts to constantly operate in a foreign language (Santti, 2001). These observational data form an important part of the research material. Moreover, another author of this article has been involved in executive training in MNB as well as consulting to the organization during the last few years. This has provided another important source of data on the role of language in the merged company, and allowed us to compare the situation in different parts of the post-merger organization. Researchers can play various roles during the course of the research process, such as a manager or consultant of the company under study. This is argued to produce insights and valid contextualization of the research phenomenon at hand (Gummesson, 1991; Johns, 2001).

Second, eight semi-structured, in-depth interviews with individuals in several Finnish units of MNB were conducted in January-March 2000. Most interviewees were middle managers and experts who responded to questions based on the following thematic structure: views on the corporate culture, the role and choice of the official corporate language, corporate culture development seminars and activities. Moreover, an in-depth interview was conducted with the former Vice CEO of the Finnish side of the bank on culture and culture development activities in MNB. All nine interviews were recorded and transcribed verbatim. In addition, nine open-ended interviews were conducted by e-mail and telephone with former employees of MNB during September and October 2000. The purpose was to assess the impact of Swedish as the corporate language on their departure from the organization after the announcement of the MNB merger. These interviewees were identified and located by using informal, personal relationships and a so-called snowballing technique (Patton, 1990: 176). This technique encourages interviewees themselves to suggest appropriate additional key informants. As a result, two of the nine interviewees represented top management, while the remaining seven occupied middle management and expert positions. They had an average tenure of eight years with MNB and its predecessors, and had left the bank soon after the merger during 1998-2000. The entire set of interview data was analysed based on transcripts or written responses returned by e-mail and categorized into meaningful themes such as the reasons for choosing Swedish as the common corporate language, the impact of Swedish on performing the job and the effect of Swedish on personal career advancement.

\section{Rationale for the common corporate language decision}


In October 1997, the Swedish Nordbanken and the Finnish Merita Bank announced their decision to merge. At the time, it was the largest merger ever to take place between Sweden and Finland measured in terms of personnel and turnover. Since the end of the 1980s, the number of mergers and acquisitions between Finnish and Swedish companies has constantly been increasing. However, 'megamergers' such as MNB demarcate a new stage of development in foreign direct investments between the two countries in terms of economic integration (Ali-Yrkko et ai, 1998). Although the ownership was divided between Merita and Nordbanken 40-60 respectively, the two merging parties had equal votes on the board of the new company. The major objective of the merger was to a build 'a regional bank of international size'. The owners and senior managers of the new bank also explicitly indicated that further geographical expansion in the Nordic and Baltic regions was part of the bank's future strategy.

Some weeks after the merger announcement, MNB made public their decision to introduce Swedish as 'the senior management language' of the bank. In support of their decision-making, the top management team used a consultancy report which portrayed a highly positive outlook on introducing Swedish as a common corporate language, neglecting possible risks associated with the decision (Santti, 2001). When asked about the motives behind selecting Swedish, top managers seemed to justify their decision by referring mainly to practical considerations. As the Vice CEO of the Finnish side of the bank commented:

There are good reasons - and there were good reasons at the time [i.e. when the common corporate language decision was made]. You really save a lot in, for example, documentation costs because documentation on one side, at least, is already in Swedish, and also part of the documentation on the Finnish side is in Swedish. If we had chosen English, we would have had all the documentation in a language foreign to both sides.

In addition to costs, the language choice was explained by referring to the poor English skills of Nordbanken staff, to corporate image and political considerations. In the corporate culture seminars, the role of Swedish as the common corporate language or a 'practical choice for communication at the corporate level' was vividly debated. Formally, the corporate management was of the opinion that Swedish would be used as an effective means 
for communication at the corporate level and within units that interacted mostly with their foreign counterparts. The CEO of the Finnish side of MNB put it as follows:

Of course, this only concerns part of the bank; it concerns the senior management and those units where people are in daily contact In Utsjoki or Rovaniemi [Finnishspeaking cities in northern Finland], language doesn't play a role.

Indeed, some former MNB employees, who at the time had worked for the international units, were not affected by top management's choice of corporate language or not even aware of it, as the daily business was largely conducted in English: 'We never took this decision seriously, because all documentation was prepared in English anyway', and 'As far as I understand, Swedish was never chosen to be the internal language of MNB'.

From the viewpoint of the Finnish-speaking organization, the corporate language decision to introduce Swedish meant that all internal communication aimed at top management had to be conducted in a new language. Not surprisingly, many Finns interpreted the use of Swedish in internal communication as a sign of Swedish dominance and this view was also strengthened in Finnish press commentaries (Risberg et al., 2003). Such a choice of corporate language was considered a clear message from top management regarding the division of authority in the merged organization. As two former MNB employees put it, 'The bank became more Swedish than Finnish', and '[At that time], there was only one voice, and one till.. .in Stockholm'. Despite the fact that Finnish and English were widely used in other internal communication or in information exchanges with customers, employees down the line started to use Swedish more broadly than its status as a 'senior management language' would have suggested. Nickerson (2000) also found in her study of British-owned subsidiaries in the Netherlands that, even though the primary receiver of the communication was not the English-speaking headquarters, English was still frequently used to ensure headquarters' access to the content of communication.

Our observational data indicate that in Sweden the top management decision was interpreted from the very beginning to mean that 'Swedish was the one and only official corporate language to be used within the new bank'. The cultural seminars showed that the Swedes regarded the choice of language as self-evident or a relief. Clearly, there was a wide gap between the initial perceptions of the common corporate language across the Finnish and Swedish sides of the organization. 
Also the views concerning the future expansion of the bank affected the debate about the common corporate language decision. In addition to the official plans, there were constant speculations and rumours concerning further mergers or acquisitions with Nordic and Baltic partners. These speculations about Swedish as a temporary corporate language solution continued until MNB made public its decision to merge with the Danish financial services group Unidanmark in March 2000. At this point, the corporate management immediately announced English as the new corporate language.

\section{Human resource implications of the common corporate language decision}

The corporate decision to introduce Swedish as the common language was negatively received among Finnish-speaking employees of the MNB organization. Many of them were confronted with a linguistic disadvantage which had significant implications for various human resource management activities.

\section{Performance appraisal}

Our empirical data suggest that the ability of Finnish-speaking employees to perform to required standards was somewhat restricted by limited competence in Swedish, the new common corporate language. Professional competence consists of deep knowledge in substance matter, argumentation skills and ability to conceptualize. In the new organization, it was also necessary to communicate effectively in the common corporate language, Swedish, as well as other customer languages. At times, however, some top Finnish experts had considerable difficulties in conveying their views and expertise in meetings in which Swedish was used. Insufficient language skills often prevented Finnish experts from contributing to meetings and discussing important professional matters. They remained silent although professionalism would have required active participation. When expressing themselves, these Finns used a very elementary form of Swedish. One interviewee described the situation at the workplace as if 'half of her professional competence had been removed'. Particular problems were also manifested in written reports in Swedish. Our observational data and interviews with present and former MNB employees clearly demonstrate how Finnish managers and members of staff felt handicapped because of limited skills in the Swedish language. Sometimes the counterpart on the other side interpreted this as lack of intellect. 
In the early phases of the merged organization, the performance appraisal of Finnishspeaking employees was particularly challenging. At that time, investments in language training had not yet materialized. Many Finns had to operate professionally without adequate levels of proficiency in the common corporate language. Consequently, these otherwise highly capable and useful employees appeared silent and unintelligent. Their professional competence was hidden behind the language barrier and they seemed to be underperforming. This impression was accentuated in situations in which a Swedish manager responsible for a Finnish-speaking unit found himself conducting appraisal interviews through an interpreter. In the merged organization, the principle of providing every employee the right to carry out appraisal interviews in their mother tongue could not be fully followed.

\section{Language training and management development}

After the merger it gradually became clear that the top management had had a vague and distorted idea of the aggregate level of skills in Swedish among Finnish staff in MNB. Most personal evaluations of language skills had been made years ago, and their validity was now dubious. Moreover, during the recession years in the early and mid-1990s, the bank had hardly recruited any new staff. Clearly, the number of competent Swedish speakers among Finns was insufficient to meet the daily communication requirements in the new organization. In our case, the Finnish organization first undertook heavy investments in building language competencies in Swedish. Thereafter, investments were made in English, which was subsequently made the corporate language.

Language training at MNB took a variety of forms, from self-study and basic external training courses, to personal training and intensive courses in Finland and abroad (Santti, 2001). Intensive courses in Swedish became very popular among Finnish-speaking employees. Reaching an adequate level of language competence was considered important to handle everyday communication with Swedish colleagues, but also to steer future career progression in a positive way. However, due to cost considerations those responsible for the MNB's language policy had to limit participation in these courses to employees who were in daily contact with the Swedes.

Another avenue for building language competence in the merged organization is through recruitment. Competence in English and Swedish was made a prerequisite for new recruits. Such 'buying in' of language skills can be a partial solution to costly and time- 
consuming development of language competence on a long-term basis (Marschan-Piekkari et al., 1999a). However, at the time, MNB was largely recruiting from inside its own organization.

While the focus of language training in MNB was on Swedish, it should be noted, however, that English language training was also offered. English was frequently used as the standard practice in banking and several MNB units provided a service to Englishspeaking customers in English. Consequently, while the daily oral communication was in Swedish, all written material was produced in English.

The imposition of a new corporate language may create tension between language demands versus professional requirements on the job. Employees have limited time and capacity to invest in training and professional development. Some Finnish MNB employees were able to overcome this dilemma by participating in management development courses which were offered in Swedish. Others did not find them attractive, mostly due to language considerations.

\section{Career paths and promotion}

In order to reach the top echelons of MNB, fluency in Swedish was a prerequisite. MNB had adopted an alternation approach between the Finnish and Swedish top managers. First, a Swede, who was based at corporate headquarters in Stockholm, was appointed CEO of MNB. A Finn, in turn, was appointed chairman of the board of directors, and based in Helsinki. He was, however, to hold this position only for the first full year following the merger. The position was then to be handed over to another Swede, and the Finn was to become vice chairman. All the Finnish top managers were comfortable using Swedish in the workplace.

Imposing Swedish as the corporate language brought about a situation in which the language skills of those running for promotion received considerable attention. It was not uncommon to hear Finnish-speaking staff blaming their Swedish-speaking colleagues for unearned increments. They raised doubts as to whether staff with language advantage were promoted 'just thanks to their skills in Swedish' without sufficient professional competence or experience. 
Our data show that the career paths of some Finnish-speaking employees were diverted because of the common corporate language. They sought to escape the Swedish language through internal mobility. Such 'Finnish-speaking havens' could be found, for example, within the domestic Finnish branch network. These employees typically avoided direct contacts with their counterparts in Sweden. Although staff rotation and expatriate assignments were considered important in unifying the merged organization, and international experience was valued in promotion, employees seldom moved across borders. For example, it would have been very challenging for a Swedish manager to accept a position in Finland and make a career in a Finnish-speaking workplace.

Employees who left the new bank did not openly admit that the choice of Swedish as a common corporate language had directly affected their decision to leave or change their career plans. Many had worked in international positions within MNB and primarily used English in their everyday communication. In addition, based on self-assessment of their skills in Swedish, most of them regarded themselves as rather or very fluent speakers of Swedish and were eager to use their skills. Yet, the common corporate language decision did matter, as one interviewee commented: 'Indirectly, language might have influenced [my decision to change jobs], because MNB seemed to lose some of its international appeal when becoming more Swedish.'

In the long run, corporate language may affect the organization's ability to retain professionals and provide them with meaningful career opportunities. Informally, language competence may excessively influence decisions concerning staff selection and promotion. The choice of the corporate language may operate as a glass ceiling, ${ }^{\wedge}$ preventing promising individuals with management talent from advancing in the organization. Moreover, as the above quotation indicates, the common corporate language may shape the corporate identity and send unintended signals to current employees and potential recruits.

\section{Key personnel}

The specific position of the Swedish-speaking Finns, and those fluent in Swedish, deserves attention. Once the merger decision had been made, this group of employees already possessed the necessary language skills to interact actively with the other party. They were equipped and prepared to meet the new communication requirements. Many Swedishspeaking Finns benefited considerably from the new language policy, finding themselves in 
influential positions within the new, post-merger organization. Given their language skills, they became important gatekeepers and liaisons between various groups of individuals. In addition, their access to corporate information was far better than that of those who spoke only Finnish. For example, two former MNB employees, who were highly competent in Swedish, had been on foreign assignments in London and Singapore. As some of the corporate communication was distributed in Swedish to foreign branches, they tended to act as translators and intermediaries for their local, English-speaking colleagues. The Swedishspeaking employees became 'language nodes' (Marschan- Piekkari et ai, 1999a: 386) because they operated as interfaces, through language, between various groups of the merged organization.

However, for some Swedish-speaking Finns the language advantage turned into a disadvantage. They had to be 'protected' from being overloaded by work as 'translation machines'. Our empirical evidence suggests that knowledge of Swedish operated like a double-edged sword: it stretched the normal job description and responsibility, but it also extended personal communication relationships, improved access to information, enhanced career opportunities and staff mobility.

It is worth noticing, however, that the Swedish language spoken by the Swedishspeaking Finns differs from rikssvenska spoken in Sweden in terms of the level of formality, certain words and pronunciation. The Swedes frequently view this dialect as awkward and old-fashioned. In our study, texts already translated and checked by a Swedish-speaking Finn had to be retranslated by a Swedish colleague to match rikssvenska, the 'real' Swedish spoken by the 'real' Swedes. The lengthy paths of translation were time-consuming and costly. From this perspective, one can question whether cost savings, which were used as a rationale for the original choice of the corporate language, ever materialized. Moreover, as a procedure, retranslation was humiliating and de-motivating for a number of Swedish-speaking Finns who saw their work being modified by colleagues from Sweden before being deemed acceptable (Santti, 2001).

\section{Concluding remarks}

The purpose of this article was to examine the human resource implications of the common corporate language decision in a cross-border merger. Traditionally, research on mergers and acquisitions has been dominated by economic considerations. It is only relatively recently 
that socio-cultural issues have come to the fore. Researchers in the area emphasize the role of communication in reducing uncertainty perceived among employees in the merger integration phase (Bastien, 1987; Napier era/., 1989; Schweiger et at., 1994; Schweiger and Denisi, 1991). However, these studies have largely adopted a domestic focus and, therefore, neglected the problems associated with language in a multilingual and multicultural organization.

The purpose of introducing a common corporate language in the merged organization is to promote integration of two previously separate entities. The analysis of the crossborder merger between the Finnish Merita Bank and the Swedish Nordbanken (creating MeritaNordbanken, MNB) shows, however, that the decision to root Swedish as the 'senior management language' had disintegrating effects on the organization. The common division into 'us' and 'them', which tends to prevail in many mergers and acquisitions, followed language-based groups in MNB alongside the traditional organizational boundaries of the acquired versus the acquiring organization. Top managers did not have a realistic understanding of the level of language competence within the organization, not even in managerial ranks. The strong emotional reactions among Finnish-speaking employees took them by surprise. In retrospect, however, the Finnish top managers admitted that the common corporate language decision could be considered a mistake. Our findings suggest that top management needs to work through the consequences of the common corporate language decision upon those who are expected to make such a decision work.

Furthermore, our study demonstrates how the introduction of a new corporate language in a cross-border merger may restrict equal opportunities between employees of merging organizations and cause unfavourable disintegration. More specifically, our study shows that language skills constitute an important element of performance appraisal. Employees who operate in a foreign language are placed in disadvantageous positions compared to those who are able to express themselves in their mother tongue. Given the insufficient level of the Finns' competence in Swedish, MNB started to invest significantly in language training. Finnish employees were also offered the opportunity to participate in management development courses in Swedish. Our data also demonstrate how career paths and promotion opportunities are prone to be language-dependent. Some Finnish-speaking employees escaped to those parts of the merged organization in which Swedish was not used. Those Finns whose mother tongue was Swedish or who were fluent in Swedish became key 
persons in the new organization. They acted as critical gatekeepers or 'language nodes' (Marschan-Piekkari et al., 1999a: 386). At times, however, they were overwhelmed by the requests to translate company material and their language skills were not always appreciated by their Swedish-speaking colleagues in Sweden. Our study illustrates how Swedish as the common corporate language unintentionally undermined the integration efforts that were being introduced within the new organization.

Many rewarding research avenues can be followed on the basis of the present research. Our study is limited to the Finnish perspective. It would be interesting to incorporate more Swedish material in order to compare the two parts of the organization. Laine-Sveiby (1991) studied communication and cultural differences in Finnish-owned subsidiaries operating in Sweden from both Finnish and Swedish viewpoints. Her findings suggest that the common corporate language may also be a challenge for those who are allowed to use their mother tongue, because they realize the danger of one-way communication. Although internationally operating companies frequently adopt one common corporate language, a particularly interesting question would be to examine language diversity in the workplace. In our case study, MNB employees switched between Finnish, Swedish and English depending on the situation and communication requirements. In multilingual organizations such as MNB, language is a distinguishing feature between individuals. This may also be viewed as a resource to be effectively exploited in diversity management in multinational corporations.

\section{Acknowledgement}

We would like to acknowledge Denice Welch's helpful comments on an earlier version of this paper.

\section{Notes}

1 The company was renamed Nordea in 2000.

2 While the term 'glass ceiling' has typically been used to denote social barriers that women face when aspiring to reach top management positions in companies, our evidence indicates that lack of language skills may have a similar, segregating effect.

\section{References}


Ali-Yrkko, J., Hemesniemi, H., Makinen, M. and Pajarinen, M. (1998) Suomen ja Ruotsin Talouseldmdn Integroituminen (Integration of Finnish and Swedish Economics, in Finnish), Discussion paper no. 658. Helsinki: The Research Institute of the Finnish Economy (ETLA).

Bamer-Rasmussen, W. (2003) Knowledge Sharing in Multinational Corporations: A Social Capital Perspective, $\mathrm{PhD}$ thesis, Helsinki: Yliopistopaino, Swedish School of Economics and Business Administration, number 113.

Bamer-Rasmussen, W. and Bjorkman, I. (2003) 'The Impact of Language and Interaction Ties on Interunit Social Capital in the MNC. In Barner-Rasmussen, W. (ed.) Knowledge Sharing in Multinational Corporations: A Social Capital Perspective, $\mathrm{PhD}$ thesis, Helsinki: Yliopistopaino, Swedish School of Economics and Business Administration, number 113.

Bastien, D.T. (1987) 'Common Patterns of Behaviour and Communication in Corporate Mergers and Acquisitions', Human Resource Management, 26(1): 17-33.

Berry, J.W. (1983) 'Acculturation: A Comparative Analysis of Alternative Forms'. In Samuda, R.J. and Woods, S.L. (eds) Perspectives in Immigrant and Minority Education. Lanham, MD: University Press of America.

Buono, A.F. and Bowditch, J.L. (1989) The Human Side of Mergers and Acquisitions: Managing Collisions between People, Cultures, and Organizations. San Francisco, CA: Jossey-Bass.

Calori, R., Lubatkin, M. and Very, P. (1994) 'Control Mechanisms in Cross-Border Acquisitions: An International Comparison', Organization Studies, 15(3): 361-79.

Cartwright, S. and Cooper, C. (1990) 'The Impact of Mergers and Acquisitions on People at Work: Existing Research and Issues', British Journal of Management, 1: 65-76.

Cartwright, S. and Cooper, C. (1993) 'The Psychological Impact of Mergers and Acquisitions on the Individual: A Study of Building Society Managers', Human Relations, 436: 327-47.

Clark, T., Cospel, H. and Montgomery, J. (1999) 'Running on the Spot? A Review of Twenty Years of Research on the Management of Human Resources in Comparative and International Perspective', International Journal of Human Resource Management, 10(3): $520-44$. 
The Economist (1999a) 'How to Make Mergers Work?', 9 January: 13

The Economist (1999b) 'After the Deal', 9 January: 19-20.

The Economist (2000a) 'How Mergers Go Wrong?', 22 July: 17.

The Economist (2000b) 'The DaimlerChrysler Emulsion', 29 July: 69-70.

The Economist (2000c) 'Schrempp's Trap', 25 November: 24.

Feely, A.J. (2003) 'Communication across Language Boundaries*. In Tayeb, M. (ed.) International Management. Harlow: Pearson Education.

Feely, A.J. and Harzing, A.W. (2003) 'Language Management in Multinational Companies', Cross-cultural Management: An International Journal, 10(2): 37-52.

Financial Times (2001) 'Tongue-Tied in Stuttgart', 27 February: 19

Flick, U. (2002) An Introduction to Qualitative Research. London: Sage.

Gertsen, M.C. and S0derberg, A.-M. (1998) 'Different Approaches to Understanding of Culture in Mergers and Acquisitions'. In Gertsen, M.C, S0derberg, A.-M. and Torp, J.E. (eds) Cultural Dimensions of International Mergers and Acquisitions. Berlin: de Gruyter.

Gertsen, M.C, S0derberg, A.-M. and Torp, J.E. (eds) (1998) Cultural Dimensions of International Mergers and Acquisitions. Berlin: de Gruyter.

Gummesson, E. (1991) Qualitative Methods in Management Research. Newbury Park, CA: Sage.

Hambrick, D. and Cannella, A. (1993) 'Relative Standing: A Framework for Understanding Departures of Acquired Executives', Academy of Management Journal, 36: 733-62.

Hogan, E.A. and Overmyer-Day, L. (1994) 'The Psychology of Mergers and Acquisitions', International Review of Industrial and Organizational Psychology, 9.

Holden, N.J. (2002) Cross-cultural Management: A Knowledge Management Perspective. Harlow: Pearson Education. 
Johns, G. (2001) 'In Praise of Context (commentary)'. Journal of Organizational Behaviour, 22: $31-42$.

Kauppalehti (2000) 'Aventis Opettelee Saksalais-ranskalaista Yhteistyota' (Aventis Practices German-French Collaboration, in Finnish), 27 September: 13.

Kay, 1.T. and Shelton, M. (2000) 'The People Problem in Mergers', The McKinsey Quarterly, 4: 27-37.

Laine-Sveiby, K. (1991) Foretag i Kulturmoten: Tre Finldndska Foretag och Deras Svenska Dotterholag: En Fthnologisk Studie. (Companies in Cultural Encounters: Three Finnish Companies and Their Swedish Subsidiaries: An Ethnographic Study, in Swedish) PhD thesis. The University of Stockholm: Akademitryck AB.

Larsson, R. and Risberg, A. (1998) 'Cultural Awareness and National versus Corporate Barriers to Acculturation'. In Gertsen, M.C, S0derberg, A.-M. and Torp, J.E. (eds) Cultural Dimensions of International Mergers and Acquisitions. Berlin: de Gruyter.

Lohrum, C (1996) Post-acquisition Integration: Towards an Understanding of Employee Reactions, $\mathrm{PhD}$ thesis. Helsinki: Swedish School of Economics and Business Administration.

Louhiala-Salminen, L. (2002) Communication and Language Use in Merged Corporations: Cases Stora Enso and Nordea, Working paper W-330. Helsinki: Helsinki School of Economics.

Marschan-Piekkari, R., Welch, D. and Welch, L. (1999a) 'Adopting a Common Corporate Language: IHRM Implications', International Journal of Human Resource Management, 10(3): 377-90.

Marschan-Piekkari, R., Welch, D. and Welch, L. (1999b) 'In the Shadow: The Impact of Language on Structure, Power and Communication in the Multinational', International Business Review, 8(4): 421-40.

Morosini, P. and Singh, H. (1994) 'Post-Cross-Border Acquisitions: Implementing "NationalCulture-Compatible" Strategies to Improve Performance', European Management Journal, 12(4): 390-400. 
Nahavandi, A. and Malekzadeh, A.R. (1988) 'Acculturation in Mergers and Acquisitions', Academy of Management Review, 13(1): 79-90.

Napier, N.K., Simmons, G. and Stratton, K. (1989) 'Communicating during a Merger: The Experience of Two Banks', Human Resource Planning, 12(2): 105-22.

Niekerson, C (2000) Playing the Corporate Language Game: An Investigation of the Genres and Discourse Strategies in English Used by Dutch Writers Working in Multinational Corporations, PhD thesis. Amsterdam: Rodopi, University of Utrecht.

Olie, R. (1994) 'Shades of Culture and Institutions in International Mergers', Organization Studies, 15(3): 381-405.

Patton, M. (1990) Qualitative Evaluation and Research Methods, 2nd edn. Beverly Hills, CA: Sage.

Pettigrew, A.M. (1972) 'Information Control as a Power Resource', Sociology, 6(2): 187-204.

Risberg, A. 1999) Ambiguities Thereafter: An Interpretative Approach to Acquisitions, $\mathrm{PhD}$ thesis. Lund: Lund University.

Risberg, A., Tienari, J. and Vaara, E. (2003) 'Making Sense of a Transnational Merger: Media Texts and the (Re)construction of Power Relations', Culture and Organization, 9(2): $121-37$.

Sales, A.L. and Mirvis, P.H. (1984) 'When Cultures Collide: Issues in Acquisitions'. In Kimberley, J.R. and Quinn, R.E. (eds) New Futures: The Challenge of Managing Corporate Transitions. Homewood, IL: Dow Jones-Irwin.

Schweiger, D.M. and Denisi, A.S. (1991) 'Communicating with Employees Following a Merger: A Longitudinal Field Experiment', Academy of Management Journal, 34(1): 110-35.

Schweiger, D.M., Csiszar, E. and Napier, N.K. (1994) 'Implementing International Mergers and Acquisitions', Human Resource Planning, 16(1): 53-70.

Santti, R. (2001) How Cultures Interact in an International Merger: Case MeritaNordbanken, $\mathrm{PhD}$ thesis. Tampere: Tampere University. 
UNCTAD (United Nations Conference on Trade and Development) (2000) 'Cross-Border Mergers and Acquisitions and Development', World Investment Report. New York and Geneva.

Vaara, E. (2000) 'Constructions of Cultural Differences in Postmerger Change Processes: A Sensemaking Perspective on Finnish-Swedish Cases', Man@gement, 32: 81-110.

Victor, D. (1992) International Business Communication. New York: HarperCollins. Weber, Y., Shenkar, O. and Raveh, A. (1996) 'National and Corporate Cultural Fit in Mergers/Acquisitions: An Exploratory Study', Management Science, 42(8): 1215-27.

Westwood, R. and Linstead, S. (2001) The Language of the Organisation. London: Sage.

Yoshihara, H. (2001) 'Global Operations Managed by Japanese and in Japanese'. In Taggart, J.H., Berry, M. and McDermott, M. (eds) Multinationals in a New Era. Basingstoke: Palgrave. 